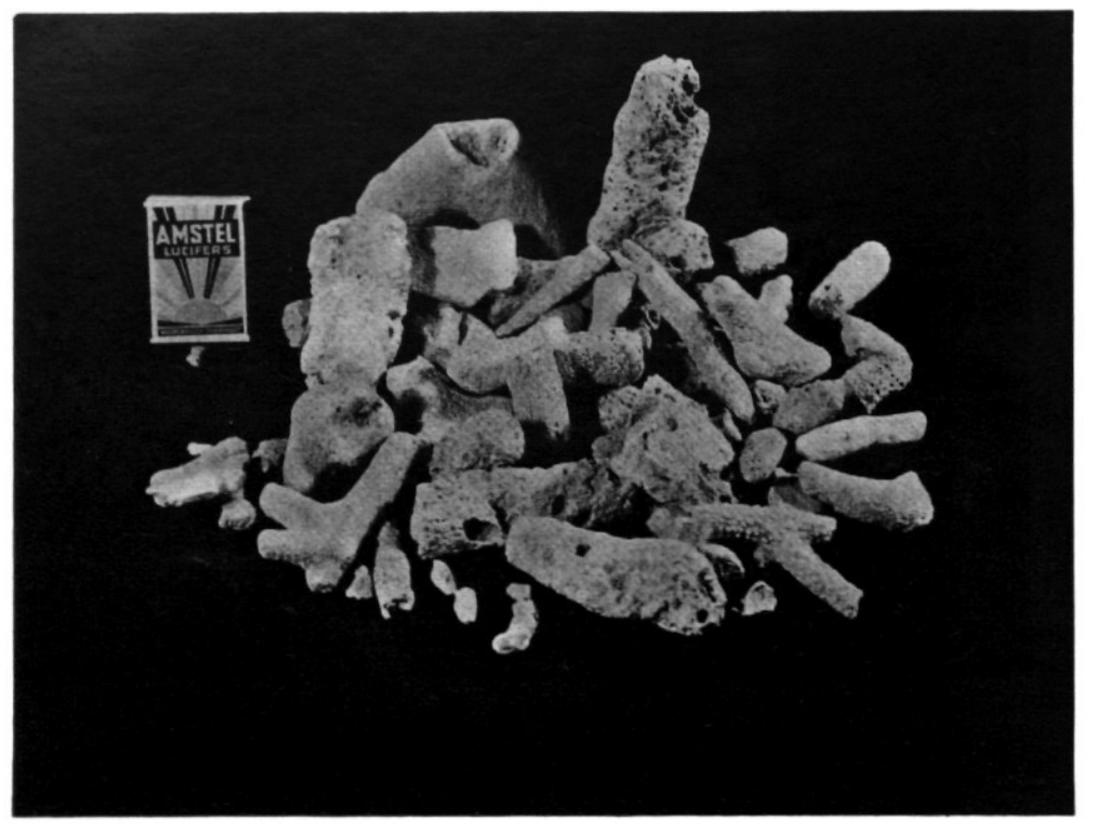

Coll. Indisch Instituut, Koraalpuin van Bonaire. 


\title{
KORAALPUIN, EEN MERKWAARDIG BOUWMATERIAAL VAN DE NEDERLANDSE ANTILLEN
}

\author{
DOOR
}

IR. W. SPOON EN WA. M. SESSELER, CHEM. DRA.

Afdeling Tropische Producten van het Indisch Instituut, Amsterdam.

In vroeger jaren is op de Benedenwindse eilanden van de $\mathrm{Ne}$ derlandse Antillen een merkwaardige bouwwijze ontwikkeld, die berustte op het gebruik van het koraalpuin (verg. de foto), waarover steeds in voldoende mate beschikt kan worden. Wij hadden daaromtrent toevallige berichten ontvangen, maar de heer A. M. SсHÜTTE, oud-gouvernementsontvanger en oud-wnd. gezaghebber van Aruba, was zo vriendelijk er ons het volgende over mede te delen.

Vijftig en meer jaren geleden werden op Curaçao huizen gebouwd uit koraalpuin en een soort klei, bij voorkeur een soort tras afkomstig van St. Eustatius. Toen cement in gebruik kwam, veranderde de bouwwijze, doordat nu het koraalpuin in een mengsel met cement en zand werd opgenomen om beton te vervaardigen. Koraalpuin neemt hier dus de plaats in van het grint of steenslag uit het betonmengsel. In houten vormen worden betonblokken vervaardigd in twee maten en wel ongeveer $30 \times 20 \times 10 \mathrm{~cm}$ en ongeveer $30 \times 10 \times 10 \mathrm{~cm}$. Naar de heer ScHütTe zich meent te herinneren is de samenstelling van het mengsel ongeveer twee delen koraalpuin op één zand en één cement. De dikke blokken (breed $20 \mathrm{~cm}$ ) dienen voor de buitenmuren, de dunne van $10 \mathrm{~cm}$ voor de binnenmuren. Net als bakstenen worden de betonblokken tot muren opgebouwd, met cement tot één geheel verbonden en daarna op de normale wijze gepleisterd.

Voor dit betonmengsel vindt men op elk der eilanden voldoende koraalpuin, de cement moet echter worden aangevoerd, terwijl men op Curaçao bij voorkeur het zand van Aruba haalt, omdat het zand ter plaatse niet voldoende vrij van zout is.

Tot zover de mededelingen van de heer ScHütTE, 
Wij hadden ons voor dit koraalpuin geïnteresseerd, omdat wij bij onderzoek in het scheikundig laboratorium van monstermateriaal, dat ons einde 1947 van Bonaire was gezonden ten behoeve van diorama's in de Antillenzaal van het museum (H.M. no. 5589), daarin niet onbelangrijke hoeveelheden zout hadden aangetroffen. Bij eerste contrôle bleek dat ruim $6 \%$ te zijn. Daarna is het materiaal met behulp van zeven met openingen van 5 en $2 \mathrm{~mm}$ doorsnede gescheiden in drie fracties, nl. de fractie groter dan $5 \mathrm{~mm}$, z.g. fijn, resp. grof grint, en stenen, de fractie 5 tot $2 \mathrm{~mm}$, fijnste deel van het grint en zand, en tenslotte de fractie kleiner dan $2 \mathrm{~mm}$, de z.g. slibfractie. Voor benaming en indeling volgden wij het Normaalblad N 209.

Van elk dezer fracties werd na vermalen en zeven op $0.5 \mathrm{~mm}$ het zoutgehalte bepaald en berekend als keukenzout.

Wij kunnen de gevonden waarden in onderstaande tabel samenvatten:

Zoutgehalte van koraalpuin

\begin{tabular}{c|c|c|c}
\hline fijnheid & $\begin{array}{c}\text { groter } \\
\text { dan 5 mm }\end{array}$ & 5-2 mm & $\begin{array}{c}\text { kleiner } \\
\text { dan 2 mm }\end{array}$ \\
\hline zout & $0.8 \%$ & $1.8 \%$ & $4.1 \%$ \\
\hline na vermalen en zeven op & & & \\
0.5 mm & & & \\
groter dan 0.5 mm . . . . \\
kleiner dan 0.5 mm . . . & $0.5 \%$ & $0.9 \%$ & $1.6 \%$ \\
& $2.4 \%$ & $2.75 \%$ & $6.6 \%$ \\
\hline
\end{tabular}

Zoals te verwachten is blijkt dat het fijnste gedeelte het meeste zout bevat; de verschillen worden groter naarmate van fijner materiaal wordt uitgegaan. Het zout bevindt zich dus hoofdzakelijk aan de oppervlakte. Dit is natuurlijk het gevolg van de voortdurend plaats grijpende verdamping. Daar het op het koraal achter blijvende zout verontreinigd is, laat zich gemakkelijk begrijpen, dat het water aantrekt (nat worden van zout). Het zal daarom met het oog op ,,werking" van de met het koraalpuin vervaardigde betonblokken van belang zijn, dat de stukgrootte niet te klein is - wij denken aan groter dan $5 \mathrm{~mm}-$ al dient 
bij de keuze van de stukgrootte ook gelet te worden op de grofheid dan wel fijnheid van het in het betonmengsel te verwerken zand.

Het is daarom belangwekkend van de heer SchütTE te vernemen, dat hij nimmer gehoord had van moeilijkheden als uitslag e.d. op de muren van huizen, gebouwd uit de beschreven betonblokken, hoewel het al minstens 15 jaar geleden is, dat huizen op die manier werden vervaardigd.

Een bevestiging nu vonden wij in het onlangs verschenen artikel van ir. J. F. Groote: De nieuwe havens van Aruba en Curaçao 1). In de nieuwe haven van Oranjestad op Aruba worden de kaden opgebouwd uit zware betonblokken. Ter plaatse is uit het baggerwerk in onbeperkte mate zand met steenslag beschikbaar. welk z.g. koraalzand echter zouthoudend is. Er werd daarom een onderzoek ingesteld of met dit zand een behoorlijk beton te bereiden was, dan wel dat zand gebruikt diende te worden van elders op Aruba, dat zoet is (de heer SchütTE maakte daar eveneens gewag van). Tevens werd in het onderzoek betrokken de vraag of in het beton zeewater mag worden gebruikt dan wel dat leidingwater (zoet water derhalve, dat op Aruba schaars en kostbaar is, omdat het er door destillatie uit zeewater moet worden gewonnen) moet worden gebezigd. In het algemeen waren de resultaten met zout zand en zout water de gunstigste, maar voor alle zekerheid is tenslotte besloten wel zout zand (het z.g. koraalzand) doch geen zeewater te gebruiken.

Het hindert dus blijkbaar onder de op de eilanden heersende klimaat-omstandigheden niet, dat er in betonwerken enig zout terecht komt. Het locale gebruik van koraalpuin in plaats van steenslag voor lichte betonconstructies (huizenbouw) wint daardoor aan betekenis.

Amsterdam, Juli 1949.

1) Ingeneur 6I, B 51 (1949). 


\title{
DEBRIS OF CORAL AS A BUILDING MATERIAL IN THE NETHERLANDS WEST INDIES
}

\author{
BY
}

W. SPOON and WA. M. SESSELER

(Tropical Products Department of the Royal Institute for the Indies, Amsterdam)

\section{SUMMARY}

On the islands of Curaçao, Aruba and Bonaire houses often are built from small blocks of concrete. Normally concrete is composed of sand, gravel and cement, but here the gravel is replaced by debris of coral, because gravel does not occur on the islands.

After studying these debris of coral in the laboratory, it appears that they contain a fair amount of salt. This salt occurs for the greater part on the surface of the pieces and as it is rather impure it has a tendency to make the debris wet.

Still, in the houses built from the blocks the salt adhering to the debris does not cause any trouble. This must be due to the extraordinary climatical conditions on the Leeward Islands. A confirmation of this theory we found in the fact that in the construction in concrete of the quay-walls in the new harbour of Oranjestad, Aruba, coralsand is used dredged out of the harbour, which sand, although containing salt, could be used very well (viz the article by J. F. Groote in Ingenieur May 13th, 1949). 